\title{
Environmental Investigations Using Diatom Microfossils
}

\section{Coastal Wetlands}

Coastal wetlands are dynamic ecosystems that are subjected to numerous long- and short-term disturbances including sea-level rise, subsidence, and storms. These ecosystems provide numerous ecological and societal services; therefore, understanding the long-term effects of disturbances on coastal wetland processes is essential when examining long-term wetland persistence and the impacts of coastal management decisions. Historical ecological data on coastal wetlands and the response of wetland communities to disturbance are sorely lacking; this lack of data results in substantial uncertainty when investigating future scenarios of climate change, population growth, subsidence, and sea-level rise.

Under normal conditions, coastal wetland sediments build vertically over time, preserving past environmental conditions within the sedimentary column. Using proxies (substitutes) for ecological or climatic conditions, scientists can reconstruct environmental change through time. Paleoecological proxies, such as pollen, charcoal, and both macrofossils and microfossils, provide a valuable tool for examining historic wetland change and making long-term predictions of wetland longevity.

\section{Diatom Microfossils}

Diatoms provide an exceptional tool for examining environmental change. Diatoms are sensitive to environmental conditions, respond rapidly to environmental change, and preserve well within most sediments. For these reasons, diatom microfossils are a paleoecological proxy for climate change (Fritz and others, 1991), sea-level rise (Fletcher and others, 1993), catastrophic events (Parsons, 1998), and various water chemistry parameters (Rosén and others, 2000).
Diatoms are unicellular phytoplankton (microscopic plant-like organisms) with cell walls made of silica (called a frustule). They live in both freshwater and saltwater and can be found in just about every place on Earth that is wet. The shape and morphology of the diatom frustule unique to each species are used for identification. Due to the microscopic size of diatoms, high-power microscopy is required for diatom identification.

Diatoms are vital to life on Earth. They are photosynthetic primary producers, using sunlight to create oxygen and organic carbon from carbon dioxide and water. They are a significant source of the oxygen we breathe, have a major impact on the global carbon cycle (Smetacek, 1999), and are a food source for many aquatic organisms (Mann, 1993). Diatom abundance has even been demonstrated to have an influence on the diversity of larger marine mammals, including whales (Marx and Uhen, 2010). Data on diatom abundance and diversity are extremely useful in environmental studies.

Diatoms are extremely sensitive to changes in water chemistry, with specific species being adapted to a particular environment. For that reason, they are often used to track pollution and evaluate environmental health of aquatic habitats. When diatoms die, the durable frustule sinks to the bottom and is added to the sedimentary record. The diatom assemblage (or collection of diatom species) preserved at depth in a sedimentary sequence provides information on past water chemistry and environmental conditions (fig. 1). The diatom assemblage is interpreted in combination with geochemistry and sedimentary characteristics to complete reconstructions of past environments.

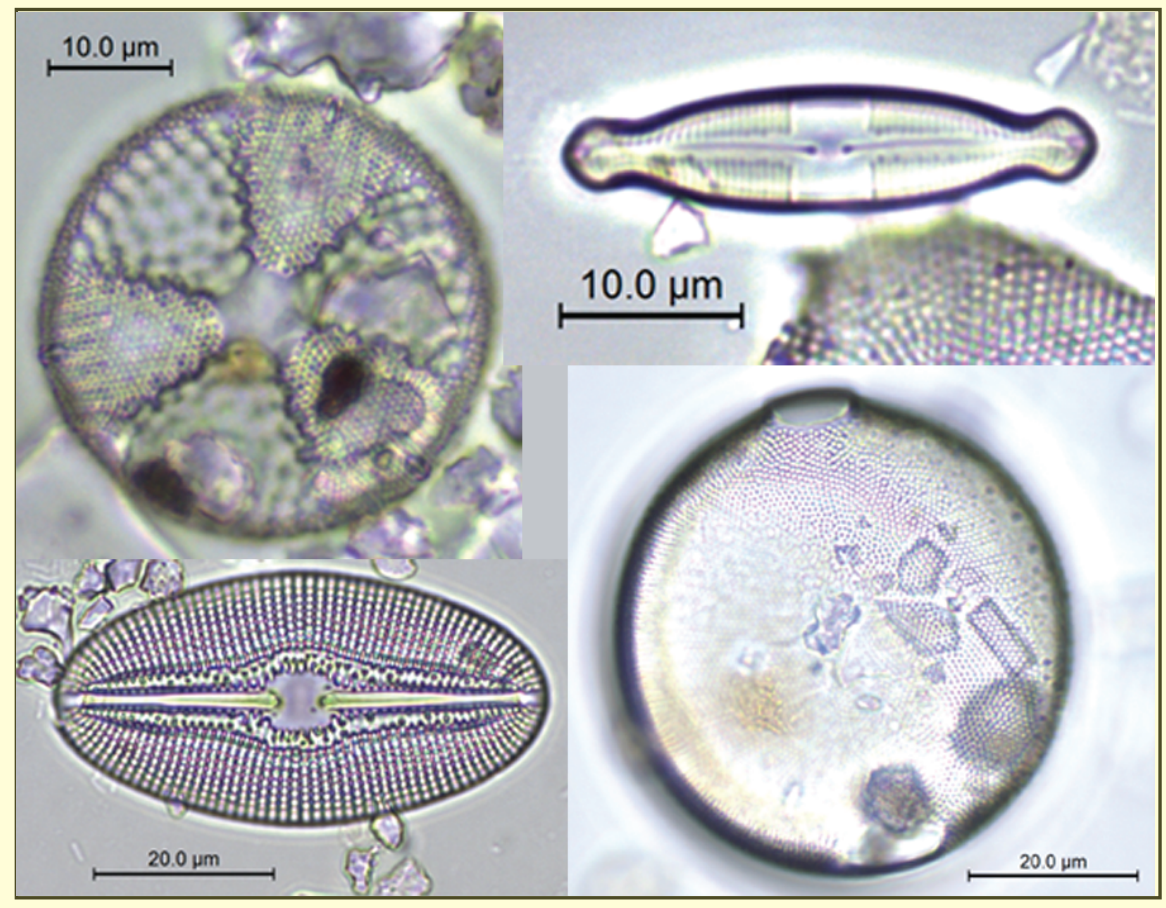

Figure 1. Diatom frustules are preserved within the sediment, providing a proxy for past water chemistry and environmental conditions. Clockwise from top left, Actinoptychus senarius (Ehrenberg) Ehrenberg, Caloneis budensis (Grunow) Krammer in Krammer \& Lange-Bertalot, Pleurosira laevis (Ehrenberg) Compère, and Diploneis smithii var. dilatata (Peragallo) Terry. A micrometer $(\mu \mathrm{m})$ is equal to $1 / 1000$ of a millimeter. 


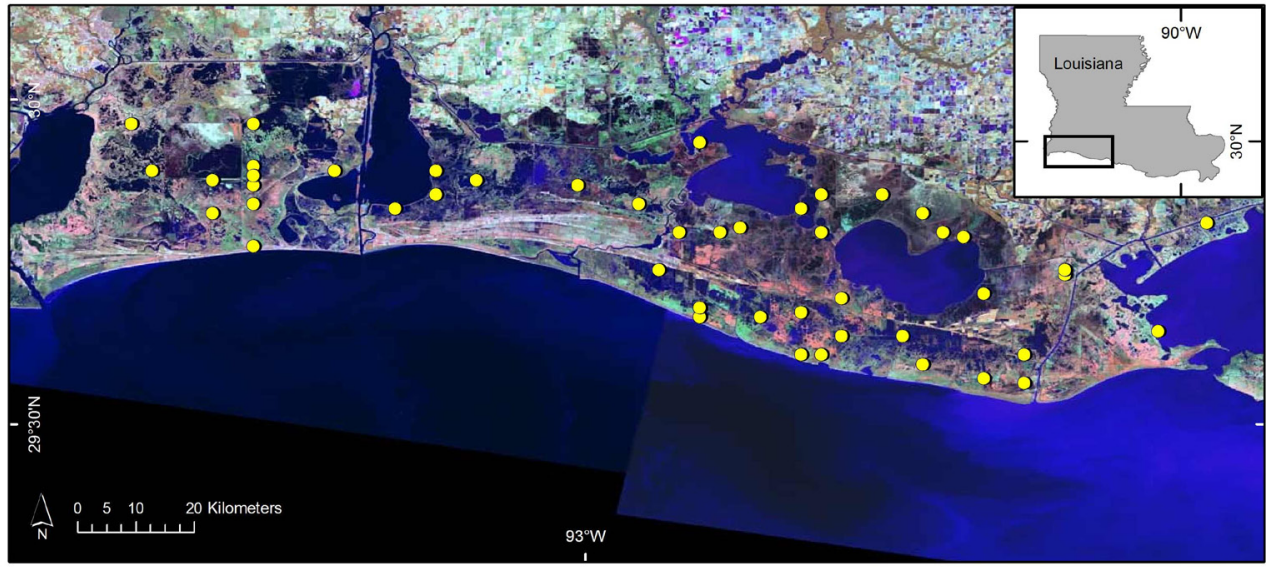

Figure 2. Over 45 sediment samples were collected from the coastal wetlands of southwest Louisiana for diatom species assessment (locations displayed as yellow dots). Each sample site is co-located with a long-term ecological monitoring station (Coast-wide Reference and Monitoring Station, CRMS) that provides vegetation and water chemistry data.

\section{Paleoreconstructions in the Northern Gulf of Mexico}

The interpretation of subsurface diatom assemblages requires detailed knowledge of the tolerances and preferences of the diatom species for a particular ecosystem. These factors necessitate a calibration dataset generated from modern species distributions. This dataset is developed by obtaining samples in known locations across an environmental gradient. The calibration dataset associates species assemblages with particular environmental conditions, therefore providing the interpretation for subsurface samples.

Analyses of coastal wetland diatom communities provide not only a regional tool for paleoecological investigations and sea-level reconstructions but also critical knowledge of wetland primary productivity and early indicators of ecosystem health. Environmental disturbances, such as oil spills, wetland loss, and coastal development, may impact diatom populations to a degree that they in turn influence higher level organisms in the food chain. The impacts of disturbances may take many years to become evident in fish, bird, or mammal populations but would be evident almost immediately within the phytoplankton community. The sedimentary column provides a record of diatom microfossil populations immediately before and after disturbance, potentially providing a straightforward pre- and post-impact assessment.

The coastal marshes of southwest Louisiana are ecologically and economi- cally important wetlands. They are also quite possibly some of the most compromised coastal habitats in the United States. The natural hydrology has been altered through the construction of shipping channels, levees, and roads, thereby reducing critical nutrient and sediment supply for marsh building. Subsidence and sea-level rise have increased wetland submergence. The combination of human activities and natural disturbances has caused significant marsh loss in coastal Louisiana. Reduction in total marsh area is expected to have severe impacts on the local economy; therefore, coastal monitoring and restoration programs are underway.

U.S. Geological Survey scientists are collecting data on the diatom community in the coastal marshes of Louisiana (fig. 2). Sites are located coincident with Coast-wide Reference and Monitoring Stations (CRMS; http://www. lacoast.gov/ crms2/), which provide essential vegetation and water chemistry data. These data will be used to calculate calibration datasets for understanding wetland change due to subsidence, sea-level rise, and storm impacts. They can also be used to establish algae monitoring protocol, create indices for water quality monitoring, and provide calibration data for wetland modeling. Diatom analyses provide a powerful method for quantitatively assessing the fossil record and allow scientists to draw conclusions on the environmental impact of disturbances and past environmental change.

\section{References Cited}

Fletcher, C.H., III, Van Pelt, J.E., Brush, G.S., and Sherman, John, 1993, Tidal wetland record of holocene sea-level movements and climate history: Palaeogeography, Palaeoclimatology, Palaeoecology, v. 102, no. 3-4, p. 177 213.

Fritz, S.C., Juggins, S., Battarbee, R.W., and Engstrom, D.R., 1991, Reconstruction of past changes in salinity and climate using a diatom-based transfer function: Nature, v. 352, p. 706-708.

Mann, K.H., 1993, Physical oceanography, food chains, and fish stocks: a review: ICES Journal of Marine Science, v. 50, p. 105-119.

Marx, F.G., and Uhen, M.D., 2010, Climate, critters, and cetaceans: Cenozoic drivers of evolution of modern whales: Science, v. 327, p. 993-996.

Parsons, M.L., 1998, Salt marsh sedimentary record of the landfall of Hurricane Andrew on the Louisiana coast: Diatoms and other paleoindicators: Journal of Coastal Research, v. 14, no. 3, p. 939-950.

Rosén, P., Hall, R., Korsman, T., and Renberg, I., 2000, Diatom transferfunctions for quantifying past air temperature, $\mathrm{pH}$ and total organic carbon concentration from lakes in northern Sweden: Journal of Paleolimnology, v. 24, no. 2, p. 109-123.

Smetacek, V., 1999, Diatoms and the ocean carbon cycle: Protist, v. 150, no. 1, p. 25-32.

\section{Contact Information}

Kathryn E.L. Smith

kelsmith@usgs.gov

James G. Flocks

jflocks@usgs.gov

USGS St. Petersburg

Coastal and Marine Science Center

600 4th Street South

St. Petersburg, FL 33701

http://coastal.er.usgs.gov/LA-subsidence/ 